\title{
KEWENANGAN MAHKAMAH KONSTITUSI DALAM MENGUJI PERATURAN PEMERINTAH PENGGANTI UNDANG-UNDANG
}

\author{
NASRULLAH \\ UIN Mataram \\ nasrullah86rch@gmail.com
}

\section{Abstrak}

Negara hukum adalah Negara yang tatanannya diatur sebaik-baiknya oleh hukum secara hirarki agar dapat menjaga konsistensi peraturan perundang-undangan, mulai dari derajat yang paling tinggi sampai kepada derajat yang paling rendah, dan konsistensi hirarkinya dapat diuji melalui lembaga yudisial, baik Mahkamah Agung (MA) ataupun Mahkamah Konsitusi (MK). Peraturan Pemerintah Pengganti Undang-Undang (Perppu) adalah salah satu bentuk produk hukum yang terdapat dalam hirarki peraturan perundang-undangan di Indonesia.Perppu adalah produk hukum yang ditetapkan oleh Presiden dalam hal ikhwal kegentingan yang memaksa yang berada pada posisi sejajar dengan undang-undang dalam tingkatan hirarki.Di satu sisi, tidak terdapat regulasi yang secara tegas mengatur kewenangan Mahkamah Konstitusi sebagai Pengadilan Konstitusi (Constitutional Court) untuk menguji perppu, sebagaimana ditegaskan di dalam Pasal 24C ayat (1) UUD 1945, MK hanya dapat menguji undang-udang terhadap Undang-Undang Dasar. Oleh karena itu, kajian terhadap kewenangan MK dalam menguji perppu ini menjadi penting. Adapun penelitian ini adalah penelitian hukum normatif yang menjadikan norma sebagai objek kajian. Kesimpulan dari penelitian ini bahwa Mahkamah Konstitusi (MK) dapat menguji Perppu terhdap UUD 1945, jika Perppu dinyatakan sama kedudukannya dengan undangundang yang menciptakan norma hukum baru, yang menurut teori peraturan perundang-undangan harus tetap berada pada tatanan hirarki untuk menjalin konsistensi antara peraturan perundang-undangan yang lebih tinggi derajatnya dengan yang lebih rendah sebagaimana diuraikan di dalam artikel.

Kata Kunci :Kewenangan, Mahkamah Konstitusi, Menguji, Perppu. 


\section{A. Pendahuluan}

Semenjak proklamasi kemerdekaan bangsa Indonesia yang dibacakan oleh Soekarno pada tanggal 17 Agustus 1945 yang disusul dengan pemberlakuan Undang-undang Dasar (UUD) Negara Republik Indonesia pada tanggal 18 Agustus 1945, maka semenjak itulah Indonesia menjadi sebuah negara merdeka dan berdaulat yang memiliki konstitusi dasar sebagai pedoman dalam bernegara. Seiring perjalanan panjang likaliku pemerintahan, konstitusi dasar negara Indonesia telah beberapa kali mengalami penggantian dan perubahan (amandemen). Pada tahun 1949, ketika bentuk Negara Republik Indonesia diubah menjadi Negara Serikat, telah diadakan penggantian konstisui dari UUD 1945 ke konstitusi RIS tahun 1949, demikian pula pada tahun 1950, ketika bentuk negara diubah lagi menjadi Negara Kesatuan, konstitusi RIS diganti dengan UndangUndang Dasar Sementara (UUDS) tahun 1950. ${ }^{1}$ Pada masa-masa selanjutnya, perjalanan konstitusi di Indonesia tidak mengalami penggantian, tetapi perubahan atau amandemen pasca runtuhnya rezim orde baru.

Bertepatan dengan tanggal 21 Mei 1998, babak baru perjalanan bangsa Indonesia dimulai kembali ketika runtuhnya rezim orde baru yang dinahkodai oleh Presiden Soeharto yang sebelumnya menggantikan Presiden Soekarno dengan rezim orde lamanya. Pola kepemimpinan yang diselenggarakan secara diktator oleh orde baru dinilai mengkhawatirkan bagi perkembangan demokrasi di Indonesia oleh para aktivis reformasi, rasa kekhawatiran terus menghantui para reformator akan terulangnya kejadian serupa dimasa-masa yang akan datang, maka munculah inisiatif

\footnotetext{
${ }^{1}$ Jimly Asshiddiqie. Konstitusi dan Konstitualisme Indonesia (Jakarta : Sinar Grafika, 2010), hlm. 42.
} 
untuk melakukan perubahan sistem ketatanegaraan melalui amandemen UUD 1945. Gerakan reformasi di samping bertujuan menuntut pengunduran diri presiden juga menuntut perubahan sistem ekonomi, sistem politik dan sistem hukum, karena sistem ekonomi yang dibangun tidak mampu menghadapi cobaan (krisis) yang terjadi, sistem politik otoriter jauh dari nilai/paham demokrasi dan sistem hukum tidak ada kejelasan walaupun dalam UUD 1945 dengan jelas bahwa Indonesia negara berdasarkan hukum. ${ }^{2}$

UUD 1945 telah mengalami empat kali perubahan, yaitu Perubahan pertama pada tahun 1999, perubahan kedua pada tahun 2000, perubahan ketiga pada tahun 2001, dan perubahan keempat pada tahun 2002. Pasal 24 ayat (2) hasil perubahan (amandemen) ketiga bulan November 2001, berbunyi “Kekuasaan kehakiman dilakukan oleh sebuah Mahkamah Agung dan badan peradilan yang berada di bawahnya dalam lingkungan peradilan umum, lingkungan peradilan agama, lingkungan peradilan militer, lingkungan peradilan tata usaha negara, dan oleh sebuah Mahkamah Konstitusi”. Berdasarkan ketentuan pasal tersebut, lembaga pelaksana kekuasaan kehakiman di Indonesia menjadi bertambah dengan adanya Mahkamah Konstitusi (MK) sebagai Pengadilan Konstitusi (Constitutional Court) yang sebelumnya tidak ada,.

Keberadaan Mahkamah Konstitusi sebagai salah satu lembaga penyelenggara kekuasaan kehakiman yang baru di Indonesia disertai dengan beberapa kewenangan yang dimiliki sebagaimana diatur dalam Pasal 24 C UUD 1945 hasil amandemen, pada ayat (1) dan (2), yaitu “(1) Mahkamah Konstitusi berwenang mengadili pada tingkat pertama dan

\footnotetext{
${ }^{2}$ Suripto. Makalah; Wewenang Mahkamah Konstitusi Menguji Undang-undang (Jakarta : Setneg, 2007) hlmn. 1
} 
terakhir yang putusannya bersifat final untuk menguji undang-undang terhadap Undang-Undang Dasar, memutus sengketa kewenangan lembaga negara yang kewenangannya diberikan oleh Undang-Undang Dasar, memutus pembubaran partai politik, dan memutus perselisihan tentang hasil pemilihan umum. (2) Mahkamah Konstitusi wajib memberikan putusan atas pendapat Dewan Perwakilan Rakyat mengenai dugaan pelanggaran oleh Presiden dan/atau Wakil Presiden menurut Undang-Undang Dasar."

Berdasarkan ketentuan Pasal 24 C ayat (1) ditegaskan bahwa salah satu kewenangan Mahkamah Konstitusi (MK) adalah menguji undang-undang terhadap Undang-Undang Dasar (UUD). Sebagaimana diketahui, keududukan undang-undang adalah berada di bawah UndangUndang Dasar, lebih jauh ditegaskan dalam Undang-Undang (UU) No. 12 tahun 2011 tentang Pembentukan Peraturan Perundang-Undangan, pada Pasal 7 hirarki Peraturan Perundang-undangan teridiri atas :

a. Undang-Undang Dasar Negara Republik Indonesia Tahun 1945;

b. Ketetapan Majelis Permusyawaratan Rakyat;

c. Undang-Undang/Peraturan Pemerintah Pengganti UndangUndang;

d. Peraturan Pemerintah;

e. Peraturan Presiden;

f. Peraturan Daerah Provinsi; dan

g. Peraturan Daerah Kabupaten/Kota.

Ketentuan kewenangan yang dimiliki oleh MK sebagaimana telah disebutkan yaitu menguji undang-undang terhadap undang-undang Dasar, sekilas nampak telah menjadi jelas batasan dan keududukannya 
berdasarkan hirarki peraturan perundang-undangan sebagaimana di atas.Namun, pada ketentuan huruf c, terdapat dua jenis peraturan perundang-undangan yang sejajar kedudukannya yaitu Undang-Undang dengan Peraturan Pemerintah Pengganti Undang-Undang yang diselingi oleh garis miring (/). Hal tersebut kemudian menjadi sebuah pertanyaan akan siapa yang berhak menguji Peraturan Pemerintah Pengganti UndangUndang tersebut jika dinilai bertentangan, sementara disatu sisi kewenangan MK dalam melakukan uji materi hanya disebutkan menguji undang-undang terhadap UUD dan tidak disebutkan mengenai ketentuan menguji Perppu. Permasalahan ini kemudian menjadi sebuah polemik di kalangan para ahli hukum tata negara, antara kebolehan MK dalam menguji Perpu terhadap undang-undang dasar atau tidak, terutama semenjak munculnya putusan MK No. 138/ PUU-VII/ 2009 tanggal 8 Februari 2010 atas Peraturan Pemerintah Pengganti Undang-Undang Nomor 4 Tahun 2009 tentang Perubahan Atas Undang-Undang Nomor 30 Tahun 2002 tentang Komisi Pemberantasan Tindak Pidana Korupsi yang diajukan oleh Saor Siagian, SH, dkk. Permasalahan ini kembali mengemuka ketika pemerintah menetapkan Peraturan Pemerintah Pengganti Undang-Undang Nomor 1 Tahun 2020 Tentang Kebijakan Keuangan Negara DanStabilitas Sistem Keuangan Untuk Penanganan PandemiCorona Virus Disease 2019 (Covid-19) Dan/AtauDalam Rangka Menghadapi Ancaman Yang MembahayakanPerekonomian Nasional Dan/Atau Stabilitas Sistem Keuangan.

Permasalahan kewenangan dalam menguji Peraturan Pemerintah Pengganti Undang-Undang (Perpu) menjadi sebuah permasalahan kontemporer dalam ranah Hukum Tata Negara Indonesia yang menarik untuk dibahas berdasarkan perspektif UUD 1945 yang menjadi konstitusi 
dasar negara, hal ini sebagai upaya revitalisasi kelimuan untuk menuju kearah perubahan yang lebih baik dan dinamis dalam ranah hukum. Sehingga besar harapan bahwa dari hasil kajian atau pembahasan permasalahan ini dapat menjadi sesuatu yang berguna bagi kita semua dalam menjalankan kehidupan berbangsa dan bernegara di bawah naungan konsitusi yang mendekati keadilan bagi seluruh rakyat Indonesia.

\section{B. Konstitusi dan Negara Hukum}

Menurut James Bryce sebagaimana dikutif oleh C.F Strong, mendefinisikan konstitusi sebagai suatu kerangka masyarakat politik (negara) yang diorganisir dengan dan melalui hukum.Sedangkan menurut C.F Strong, konstitusi dapat pula dikatakan sebagai kumpulan prinsipprinsip yang mengatur kekuasaan pemerintah, hak-hak pihak yang diperintah (rakyat), dan hubungan di antara keduanya. ${ }^{3}$ Hans Kelsen menyatakan bahwa konstitusi merupakan jenjang tertinggi hukum positif. ${ }^{4}$ Secara lebih rinci, Kelsen membagi pengertian konstitusi menjadi dua, yaitu konstitusi dalam arti formal dan material. Konstitusi dalam arti formal adalah suatu dokumen resmi, seperangkat norma hukum yang dapat diubah di bawah pengawasan ketentuan-ketentuan khusus, yang tujuannya adalah untuk menjadikan perubahan-perubahan norma ini lebih sulit. Selanjutnya konstitusi dalam arti material terdiri atas peraturanperaturan yang mengatur pembentukan norma-norma hukum yang bersifat umum, terutama pembentukan undang-undang. ${ }^{5}$

\footnotetext{
hlm. 14-15.

${ }^{4}$ Hans Kelsen. Teori Hukum Murni (Bandung : Nusa Media, 2010), hlm. 244.

${ }^{5}$ Hans Kelsen. Teori Umum Tentang Hukum dan Negara (Bandung : Nusa Media, $2011)$, hlm. 180.
}

${ }^{3}$ C.F. Strong, Konstitusi-Konstitusi Politk Modern (Bandung : Nusa Media, 2011), 
Menurut K.C Wheare, sebagaimana dikutif oleh Juniarto menyatakan bahwa Istilah constitution pada umumnya dipergunakan untuk menunjuk kepada seluruh peraturan mengenai ketatanegaraan suatu negara yang secara keseluruhan akan menggambarkan sistem ketatanegaraan tersebut terbagi dua golongan, yaitu peraturan berderajat legal (law) dan berderajat nonlegal (extralegal). ${ }^{6}$

Di lingkungan Kerajaan Romawi (Roman Empire), perkataan constitutio dalam bentuk latinnya juga dipakai sebagai istilah teknis untuk menyebut "the acts of legislation by the Emperor". Menurut Brian Thompson secara sederhana pertanyaan: what is a constitution dapat dijawab bahwa "....a constitution is a document which contains the rules for the operation of an organization". Sedangkan menurut Philips Hood and Jackson sebagaimana dikutif oleh Jimliy, konstitusi menurutnya adalah suatu bangunan aturan, adat istiadat, kebiasaan-kebiasaan yang menentukan susunan dan kekuasaan organ-organ negara dan yang mengatur hubungan di antara berbagai organ negara itu satu sama lain, serta hubungan organ-organ negara itu dengan warga negara. Lebih jauh menurut Jimly, konstitusi adalah hukum dasar yang dijadikan pegangan dalam penyelenggaraan suatu negara.Konstitusi dapat berupa hukum dasar tertulis yang lazim disebut Undang-undang Dasar, dan dapat pula tidak tertulis. ${ }^{7}$

Menurut Lord Bryce, terdapat empat landasan dibentuknya konstitusi, yaitu:

\footnotetext{
${ }^{6}$ Juniarto, Selayang Pandang Sumber-sumber Hukum Tata Negara di Indonesia (Jakarta : Rineka Cipta), hlm. 22.

${ }^{7}$ Lihat : Jimly Asshiddiqie, Konstitusi dan Konstitualisme Indonesia (Jakarta : Sinar Grafika, 2010), hlm. 4-29.
} 
1. Adanya keinginan aggota warga negara untuk menjamin hakhaknya yang mungkin terancam dan sekaligus membatasi tindakan-tindakan penguasa;

2. Adanya keinginan dari pihak yang diperintah atau yang memerintah dengan harapan untuk memjamin rakyatnya dengan menentukan bebtuk suatu sistem ketatanegaraan tertentu;

3. Adanya keinginan dari pembentuk negara yang baru untuk menjamin tata cara penyelenggaaraan ketatanegaraan;

4. Adanya keinginan untuk menjamin kerjasama yang efektif antar negara bagian. ${ }^{8}$

Konsepsi negara hukum yang disebut istilah The Rule of Law, and not of Man berarti bahwa suatu kepemimpinan dalam pemerintahan yang sebenarnya adalah terdapat pada hukum, bukan pada orangnya. ${ }^{9}$ Maka hukum merupakan raja yang menjadi acuan bagi semua orang yang terdapat di negara tersebut, tak terkecuali kepala pemerintahan beserta segenap jajarannya.Istilah negara hukum di Indonesia berasal dari terjemahan Rechtsstaat dan Rule of Law.Sebagaimana diidentifikasi oleh Rescoe Pound, Rechtsstaat memiliki karakter administratif sedangkan the Rule of Law berkarakter yudisial.Reschsstaat bersumber dari tradisi hukum negara-negara Eropa Kontinental yang bersandar pada civil law dan legisme yang menganggap hukum adalah hukum tertulis, dan kebenaran hukum dan keadilan di dalam rechsstaat terletak pada ketentuan bahkan pembuktian tertulis. Sedangkan The Rule of Law berkembang dalam tradisi hukum negara-negara Anglo Saxon yang mengembangkan common

\footnotetext{
${ }^{8}$ Juniarto, Selayang Pandang. Op. Cit. hlm. 40-41.

${ }^{9}$ Jimly.Konstitusi. Op.Cit. hlm. 299
} 
law (hukum tak tertulis), kebenaran hukum dan keadilan di dalamnya bukan semata-mata hukum tertulis. ${ }^{10}$

Sistem hukum Romawi-Jerman adalah sistem yang dipakai di Indonesia. Di Indonesia, tampaknya ia lebih dikenal dengan nama Civil Law System, yang terjemahan harfiahnya menjadi sistem hukum sipil. ${ }^{11}$ Civil law juga biasa dikenal dengan sebutan sistem hukum eropa kontinental.Tradisi hukum Eropa Kontinental mengandalkan kitab undangundang (code) sebagai dasar hukum utamannya.Karena mengandalkan kitab undang-undang sebagai sumber hukum dan dasar hukum utamanya, maka sistem hukum Romawi sangat mengandalkan unsur-unsur logis dan sistematika berpikir. ${ }^{12}$ Perbedaan antara Eropan Kontinental dan Anglo Saxon dewasa ini lebih tertuju pada tumpuan strategi pembangunan hukumnya, yang satu menekankan pada peran lembaga legislatif dan eksekutif untuk membuat hukum-hukum tertulis, sedangkan yang satunya lebih menekankan pada peran lembaga yudisial untuk membuat hukum melalui vonis-vonisnya yang kreatif dengan menggali nilai-nilai keadilan di dalam masyarakat. ${ }^{13}$

Menurut Franz Magnis-Suseno, terdapat dua unsur dalam paham negara hukum. Pertama, hubungan antara pemerintah dan yang diperintah tidak berdasarkan kekuasaan, tetapi berdasarkan norma yang objektif juga mengikat pihak yang memerintah. Kedua, norma yang objektif itu, hukum,

\footnotetext{
${ }^{10}$ Mahfud MD, Membangun. Op.Cit. hlm. 24-25.

${ }^{11}$ Satjipto Raharjo, IImu Hukum (Bandung : Citra Adikarya, cet ke-vi 2006), hlm. 235.

${ }^{12}$ Munir Fuady, Perbandingan IImu Hukum (Bandung : Refika Aditama, 2010), hlm. 32.

${ }^{13}$ Makalah 4 Mahfud MD.MK dan Politik Perundang-undangan (www.mahfudmd.com)
} 
memenuhi syarat bukan hanya secara formal, melainkan dapat dipertahankan berhadapan dengan ide hukum. ${ }^{14}$

Albert Venn Dicey (1835-1922) mengemukakan adanya tiga prinsip yang berlaku bagi suatu negara hukum, yaitu ${ }^{15}$ :

1. Prinsip supremacy of law

2. Prinsip equality before the law

3. Prinsip the constitution based on individual rights.

Menurut Julius Stahl, konsep Negara Hukum yang disebutnya dengan istilah 'rechtsstaat' itu mencakup empat elemen penting, yaitu:

1. Perlindungan hak asasi manusia.

2. Pembagian kekuasaan.

3. Pemerintahan berdasarkan undang-undang.

4. Peradilan tata usaha Negara.

Sedangkan menurut Jimly $^{16}$, terdapat sebelas prinip pokok yang terkandung dalam negara hukum yang demokratis, yaitu :

1. Adanya jaminan persamaan dan kesejahteraan dalam kehidupan bersama;

2. Adanya pengakuan dan penghormatan terhadap perbedaan atau pluralitas;

3. Adanya aturan yang mengikat dan dijadikan sumber rujukan bersama;

4. Adanya mekanisme penyelesaian sengketa berdasarkan mekanisme aturan yang ditaati bersama itu;

5. Adanya pengakuan dan penghormatan terhadap HAM;

${ }^{14}$ Franz Magnis-Suseno, Etika Politik Prinsip Moral Dasar Kenegaraan Modern (Jakarta: Gramedia, 1999), hlm. 295.

${ }^{15}$ Astim Riyanto, Teori Konstitusi (Bandung : Yapemdo, 2006), hlm. 256.

${ }^{16}$ Jimly Asshiddiqie, Hukum Tata Negara Dalam Pilar-Pilar Demokrasi (Jakarta : Konpress, 2005) hlm. 229-300. 
6. Adanya pembatasan kekuasaan melalui mekanisme pemisahan dan pembagian kekuasaan disertai mekanisme penyelesaian sengketa ketatanegaraan antara lembaga negara, baik secara vertical maupun horizontal;

7. Adanya peradilan yang bersifat independen dan tidak memihak dengan kewibawaan putusan tertinggi atas dasar keadilan dan kebenaran;

8. Adanya lembaga peradilan yang dibentuk khusus untuk menjamin keadilan bagi warga negara yang dirugikan akiabat putusan atau kebijkan pemerintah;

9. Adanya mekanisme judicial review oleh lembaga peradilan menghadap norma-norma ketentuan legislatif, baik yang ditetapkan oleh lembaga legislative maupun eksekutif; dan

10.Dibuatnya konstitusi dan peraturan perundang-undangan yang mengatur jaminan pelaksaan prinsip-prinsip diatas.

11.Adanya pengakuan terhadap asas legalitas atau due process of law dalam keseluruhan sistem penyelenggaraan negara.

\section{Lembaga-Lembaga Negara Pasca Amandemen UUD 1945}

Setelah dilakukannya amademen terhadap Undang-undang Dasar (UUD) 1945, struktur kelembagaan negara di Indonesia mengalami perubahan. Pasca perubahan ke-empat terdapat delapan lembaga negara yang setingkat, yaitu:

1. Dewan Perwakilan Rakyat

2. Dewan Perwakilan Daerah

3. Majelis Permusyawaratan Rakyat 
4. Badan Pemeriksa Keuangan

5. Presiden dan Wakil Presiden

6. Mahkamah Agung

7. Mahkamah Konstisusi

8. Komisi Yudisial

Adapun beberapa lembaga-lembaga lain yang bersifat independen, yang dasar pembentukannya merujuk pada bunyi pasal dalam UUD 1945 adalah:

1. Komisi Pemilihan Umum

2. Tentara Nasional Indonesia dan Kepolisian Negara (TNI \& POLRI)

3. Bank Indonesia

4. Kejaksaan Agung.

Selain lembaga independen di atas, terdapat beberapa lembagalembaga khusus yang tidak diatur dalam UUD 1945, yaitu :

1. Komnas HAM

2. Komisi Pemberantasan Korupsi (KPK)

3. Komisi Ombudsmen

4. Komisi Pemeriksa Kekayaan Penyelenggara Negara (KPKPN), telah dilebur menjadi satu dengan KPK pada tahun 2004.

5. Komisi Pengawas Persaingan Usaha (KPPU)

6. Komisi Kebenaran dan Rekonsiliasi (KKR), UU terkait telah dibatalkan oleh MK pada tahun 2006.

Salah satu point penting dari hasil amandemen UUD 1945 adalah lahirnya Mahkamah Konstitusi dalam sistem ketatanegaraan Indonesia, sebagai lembaga yang berwenang untuk melaksanakan fungsi uji 
konstitusionalitas. Memperhatikan kondisi faktual yang terjadi pascaterjadinya beberapa konflik ketatanegaraan, gagasan pembentukan Mahkamah Konstitusi setidaknya didorong oleh tiga alasan ${ }^{17}$ :

1. Bertambahnya jumlah lembaga negara dan bertambahnya ketentuan sebagai akibat perubahan UUD 1945, menyebabkan potensi sengketa antar lemabaga negara menjadi semakin banyak. Sementara itu telah terjadi perubahan paradigma dari supremasi MPR kepada supremasi konstitusi, sehingga tidak ada lagi lembaga tertinggi negara pemegang supremasi kekuasaan yang berwenang menyelesaikan sengketa antarlembaga negara. Oleh karena itu, diperlukan lembaga yang netaral untuk menyelesaikan sengketa tersebut.

2. Sebagai konsekuensi dari perwujudan negara hukum yang demokratios yang berdasarkan hukum. Kenyataan menunjukan bahwa suatu keputusan yang demokratis tidak selalu sesuai dengan ketentuan hukum yang berlaku. Oleh karena itu, diperlukan suatu lembaga yang berwenang menguji konstitusionalitas UU terhadap UUD.

3. Ada kasus aktual yang terjadi di Indonesia pada saat itu, yaitu pemakzulan (impeachment) Presiden Abdurahman Wahid dari kursi kepresidenannya oleh MPR pada sidang istimewa MPR tahun 2001. Kasus ini mengilhami tercetusnya pemikiran untuk mencari cara agar ada mekanisme hukum yang membingkai proses pemberhentian Presiden dan/atau Wakil Presiden yang

${ }^{17}$ Mahkamah Konstitusi Republik Indonesia, Menegakkan Negara Hukum Yang Demokratis: Catatan Tiga Tahun Perjalanan Mahkamah Konstitusi 2003-2006, (Jakarta : Sekretariat Jendral dan Kepaniteraan MK RI, 2006) hlm. 28. 
tidak didasarkan atas alasan politis semata. Untuk itu, disepakati keperluan akan adanya suatu lembaga yang berkewajiban menailai pelanggaran hukum yang dilakukan oleh Presiden dan/atau Wakil Presiden, yang dapat menyebkan Presiden dan/atau Wakil Presiden dapat diberhentikan sebelum habis masa jabatannya.

\section{Bentuk dan Kewenangan Lembaga Judicial Review}

Yang dimaksud dengan judicial review adalah suatu pranata dalam ilmu hukum yang memberikan kewenangan kepada badan pengadilan umum, atau pengadilan khusus, ataupun lembaga khusus untuk melakukan peninjauan ulang, dengan jalan menerapkan atau menafsirkan ketentuan dan semangat dari konstitusi, sehingga dari hasil peninjauan ulang tersebut dapat menguatkan atau menyatakan batal atau membatalkan, atau menambah atau mengurangi terhadap suatu tindakan berbuat atau tidak berbuat dari aparat pemerintah (eksekutif) atau dari pihak-pihak lainnya (termasuk parlemen). ${ }^{18}$

Menurut Mahfud MD secara spesifik, Judicial review adalah pengujian oleh lembaga yudikatif tentang konsistensi UU terhadap UUD atau peraturan perundang-undangan terhadap peraturan perundangundangan yang lebih tinggi. ${ }^{19}$ Esksistensi lembagajudicial review sangat penting untuk menjamin tertibnya pengaturan dan pelaksanaan hukum agar tidak menimbulkan kekacauan pada saat diterapkan. Hal tersebut sesuai dengan pendapat Kelsen tentang tujuan hukum, sebagaimana telah

\footnotetext{
${ }^{18}$ Munair Fuady, Teori. Op. cit. hlm. 81.

${ }^{19}$.Mahfus MD.Membangun. Op. Cit. hlm. 37.
} 
dikutif oleh Khuzaifah Dimyati, yaitu untuk mengurangi kekacauan dan kemajemukan menjadi kesatuan. ${ }^{20}$

Di Indonesia, judicial review dilaksanakan oleh lembaga yudikatif selaku pelaksana kekuasaan kehakiman yang terdiri dari Mahkamah Agung (MA) dan Mahkamah Konstitusi (MK), sebagaimana dinyatakan dalam Pasal 24 ayat (2) yaitu "Kekuasaan kehakiman dilakukan oleh sebuah Mahkamah Agung dan badan peradilan yang berada di bawahnya dalam lingkungan peradilan umum, lingkungan peradilan agama, lingkungan peradilan militer, lingkungan peradilan tata usaha negara, dan oleh sebuah Mahkamah Konstitusi”.

Adapun kewenangan Mahakamah Agung (MA) dalam bidang judicial review, diatur dalam Pasal 24 A ayat (1) yaitu "menguji peraturan perundang-undangan di bawah undang-undang terhadap undangundang”. Sedangkan tugas Mahkamah Konstitusi diatur dalam Pasal 24 C ayat (1) yaitu "Mahkamah Konstitusi berwenang mengadili pada tingkat pertama dan terakhir yang putusannya bersifat final untuk menguji undang-undang terhadap Undang-Undang Dasar,". Lebih lanjut, kewenangan MK dan MA dirinci kembali di dalam UU No. 12 tahun 2011 tentang Pembentukan Peraturan Perundang-Undangan, yaitu :

(1) Dalam hal suatu Undang-Undang diduga bertentangan dengan Undang-Undang Dasar Negara Republik Indonesia Tahun 1945, pengujiannya dilakukan oleh Mahkamah Konstitusi.

(2) Dalam hal suatu Peraturan Perundang-undangan di bawah Undang-Undang diduga bertentangan dengan UndangUndang, pengujiannya dilakukan oleh Mahkamah Agung.

${ }^{20}$ Khudzaifah Dimyati, Teorisasi Hukum (Yogyakarta : Genta, 2010), hlm. 44. 
Menurut Jimly selaku mantan ketua Mahkamah Konstitusi, sebagaimana dikutif Susanto bahwa dari 78 negara yang memiliki Mahakamah Konstitusi, terdapat enam pola Mahkamah Konstitusi yang diterapkan di seluruh dunia yaitu Pola Austria, Perancis, Belgia, Amerika Serikat, Amerika Latin, dan Pola Supremasi Parlementer . Dari ke-enam pola Mahkamah Konstitusi, Indonesia menerapakan pola seperti Austria yang membentuk suatu Mahkamah Konstitusi sendiri di samping Mahkamah Agung. ${ }^{21}$

Dalam ilmu hukum dikenal dua macam judicial review, yaitu sebagai berikut ${ }^{22}$ :

1. Judicial review dalam bidang pengadilan, yang berarti review dari badan pengadilan tertinggi terhadap putusan pengadilan yang lebih rendah dengan alasan-alasan yang sangat terbatas, seperti adanya barang bukti baru (novum) atau ada kesalahan berat ketika hakim rendahan memutus perkara tersebut. Di Indonesia kewenangan seperti ini berada di tangan MA dengan sebutan Peninjauan Kembali (PK)

2. Dalam bidang hukum konstitusi, kewenangan lembaga pengadilan tertinggi untuk membatalkan putusan badan legislatif dan atau eksekutif. Pengertian judicial review seperti inilah yang digunakan di Indonesia, dan kewenangan seperti ini berada ditangan Mahkamah Konstitusi dan Mahkamah Agung.

\footnotetext{
${ }^{21}$ Agung Susanto, Hukum Acara Perkara Konstitusi (Bandung : Mandar Maju, 2006), hlm. 77.

${ }^{22}$ Munir Fuady, Teori Negara Hukum (Bandung : Refika Aditama, 2009), hlm. 82.
} 
Salah satu persyaratan agar suatu judicial review dapat dilaksanakan adalah adanya "kasus dan sengketa" (case and controversy). Umumnya, agar kewenangan judicial review dapat dijalankan, harus memenuhi persyaratan sebagai berikut :

1. Persyaratan Standing/Legal Standing

2. Persyaratan di Luar Persoalan Politik (Political Question)

3. Persyaratan Kematangan Perkara (Ripennes)

4. Persyaratan Kelanjutan Kelangsungan Kerugian (Mootness).

Adapun yang merupakan persyaratan yang bersifat teknikal yuridis bagi suatu permohonan judicial review tersebut adalah sebagai berikut:

1. Harus ada suatu perbuatan, kebijakan, produk hukum (seperti undang-undang), bahkan termasuk juga tindakan tidak berbuat.

2. Perbuatan (termasuk tidak berbuat), kebijakan atau produk hukum tersebut bertentangan dengan konstitusi

3. Adanya kerugian bagi pihak pemohon judicial review

4. Adanya nexus (hubungan sebab akibat) antara perbuatan, kebijakan, atau produk hukum di satu pihak dengan kerugian di pihak lain. ${ }^{23}$

\section{Kedudukan Perppu dalam Peraturan Perundang-undangan}

Peraturan Pemerintah Pengganti Undang-Undang (Perppu) di dalam peraturan perundang-undangan berada pada tingkatan ke-dua,

${ }^{23}$ Ibid. hlm. 95-96. 
sejajar dengan undang-undang. Hal tersebut sebagaimana dinyatakan dalam Pasal 7 UU No. 12 tahun 2011 yaitu:

(1) Jenis dan hirarki peraturan perundang-undangan terdiri atas :

a. Undang-Undang Dasar Negara Republik Indonesia Tahun 1945;

b. Ketetapan Majelis Permusyawaratan Rakyat;

c. Undang-Undang/Peraturan Pemerintah Pengganti UndangUndang;

d. Peraturan Pemerintah ;

e. Peraturan Presiden ;

f. Peraturan Daerah Provinsi; dan

g. Peraturan Daerah Kabupaten/Kota.

Kewenangan untuk membentuk Perppu berada pada presiden yaitu dalam hal kegentingan yang memaksa, hal ini berdasarkan Pasal 22 UUD 1945, yaitu :

(1) Dalam hal ikhwal kegentingan yang memaksa, Presiden berhak menetapkan peraturan pemerintah sebagai pengganti undangundang.

(2) Peraturan Pemerintah itu harus mendapat persetujuan Dewan Perwakilan Rakyat dalam persidangan yang berikut.

(3) Jika tidak mendapat persetujuan, maka Peraturan Pemerintah itu harus dicabut.

Mengingat bahwa undang-undang dasar tidak memiliki penjelasan secara resmi, maka yang dimaksud dengan kegentingan yang memaksa memungkinkan munculnya berbagai macam interpretasi atau penafsiran terhadap kategori kegentingan memaksa. 


\section{E. Konstitusi, Judcial Review dan Teori Hirarki}

Keberadaan konstitusi merupakan sesuatu yang sangat urgen dan substansial dalam penyelenggaraan negara yang berlandaskan atas hukum dan dilaksanakan dengan demokratis, tidak dapat dibayangkan suatu negara jika dibangun dan diselenggarakan tanpa sebuah konstitusi yang menjadi sebuah pedoman dalam penyelenggaraan negara. Tanpa adanya konstitusi yang mengatur hubungan-hubungan antara pemerintah dan orang yang diperintah, maka pemerintah akan bebas melaksanakan kehendaknya sesuka hati, maka dari itu diperlukan sebuah konstitusi dalam sebuah negara yang dibuat oleh rakyat untuk mengatur penguasa atau pemerintah, sehingga pemerintah dapat terkontrol dalam menjalankan pemerintahan. Hal ini senada dengan pendapat Thomas Paine sebagaimana dikutif oleh Jimly, yang menyatakan "a constitution is not the act of a government, but of people constituting a government, and a government without a constitution is power without right". ${ }^{24}$

UUD 1945 pertama kali disahkan dan berlaku sebagai konstitusi negara Indonesia dalam sidang Panitia Persiapan Kemerdekaan Indonesia (PPKI) pada tanggal 18 Agustus 1945, yaitu sehari setelah kemerdekaan negara Republik Indonesia diproklamasikan oleh Seokarno dan Mohammad Hatta pada tanggal 17 Agustus $1945 .{ }^{25}$ Semenjak itulah UUD 1945 berlaku sebagai hukum dasar dalam penyelenggaraan Negara Kesatuan Republik Indonesia (NKRI) yang merdeka, bersatu, berdaulat, adil dan makmur. Di kalangan para ahli hukum, pada umumnya dipahami

\footnotetext{
${ }^{24}$ Jimly Asshiddiqie.Pengantar Ilmu Hukum Tata Negara (Jakarta : Raja Grafindo, 2010) . hlm. 161.

${ }^{25}$ Jimly. Konstitusi.Op.Cit. hlm. 32.
} 
bahwa hukum mempunyai tiga tujuan pokok, yaitu : keadilan (justice), kepastian (certainty), dan kegunaan (utility). ${ }^{26}$

Empat tujuan bernegara di Indonesia adalah seperti yang termaktub dalam alinea IV Pembukaan UUD 1945. Keempat tujuan itu adalah : (i) melindungi segenap bangsa Indonesia dan seluruh tumpah darah Indonesia; (ii) memajukan kesejahteraan umum; (iii) mencerdaskan kehidupan bangsa; dan (iv) ikut melaksanakan ketertiban dunia (berdasarkan kemerdekaan, perdamaian abadi, dan keadilan sosial). Pada umumnya dikatakan bahwa tujuan (yang sering disamakan dengan citacita) bangsa Indonesia adalah membentuk masyarakat adil dan makmur berdasarkan pancasila. ${ }^{27}$ Tujuan bernegara sebagaimana dimaksud, tidak akan mungkin tercapai dengan tanpa adanya konstitusi, maka dari itu tujuan bernegara indoneisa pun diletakkan dalam pembukaan konstitusi dasar.

Undang-undang Dasar Negara Republik Indonesia tahun 1945 menjadi dasar utama negara dalam menjalankan negara dan sebagai induk dari undang-undang yang berada dibawahnya serta sebagai kontrol. Dalam hal keperingkatan dan perangkat/hukum, berlaku asas hukum (rechtsbeginsel) yaitu; lex supriori derogate legi inferiori artinya peraturan yang lebih tinggi jenjangya mengalahkan peraturan yang lebih rendah. ${ }^{28}$ Setiap peraturan perundang-undangan baru yang dibuat dan disahkan harus tetap memiliki kaitan konsistensi dengan peraturan perundang-undangan sebelumnya yang berada di atasnya agar tetap berada dalam tatanan hirarki.

${ }^{26}$ Jimly, Pengantar, Op.Cit hlm. 119.

27 Mahfud MD, Membangun Politik. Op. Cit. hlm, 17.

${ }^{28}$ Solly Lubis, IImu Pengetahuan Perundang-undangan (Bandung : Mandar Maju, 2009), hlm. 20. 
Di Indonesia sebagaimana telah disebutkan sebelumnya, tatanan hirarki peraturan perundang-undangan diatur dalam UU No. 12 tahun 2011 pada Pasal 7. Terkait dengan fokus bahasan pegujian Perppu oleh Mahkamah Konstitusi (MK) terhadap UUD 1945, permasalahan ini akan dielaborasi menggunakan teori hirarki peraturan perundang-undangan, penafsiran terhadap Perppu, dan konsep judicial review serta bagaimana awal kemunculunnya.

Berawal dari putusan John Marshall selaku chief justice dalam putusan kasus antara Marbury versus Madison yang diajukan ke Mahkamah Agung (supreme court) Amerika Serikat pada tahun 1801, yang kemudian diputus pada tahun 1803. Dalam putusannya, John Marshall tidak hanya memutus soal perkara yang diajukan Marbury, melainkan juga membatalkan ketentuan yang terdapat dalam judiciary act 1789 tentang writ of madamus karena dianggap bertentangan dengan article III section 2 yang merupakan konstitusi dasar Amerika Serikat pada waktu itu, meskipun pada saat yang bersamaan belum ada ketentuan yudisial review. John mengemukakan tiga alasan untuk mendasari dirinya melakukan judicial review yaitu: ${ }^{29}$

a. Hakim bersumpah untuk menjunjung tinggi konstitusi, sehingga jika ada peraturan yang bertentangan dengan konstitusi ia harus melakukan uji materi;

b. Konsitusi adalah the supreme law of the land sehingga harus ada pengujian terhadap peraturan yang di bawahnya agar isi the supreme law tidak dilangkahi;

${ }^{29}$ Lihat Mahfud.Membangun Politik. Op. cit. hlm. 125-127. 
c. Hakim tidak boleh menolak perkara, sehingga kalau ada yang mengajukan permintaan judicial review, hal itu harus dipenuhi.

Apa yang dilakukan oleh John Marshall merupakan sejarah baru bagi dunia peradilan di dalam bidang judicial review, sehingga tindakan tersebut mendapat banyak pujian diantaranya disebut sebagaia landmark decision, the most brilliant innovation, the single most important decision in American constitutional law.Kini, judicial review tidak hanya dilakukan di Amerika saja, melainkan telah menjadi inspirasi dan merambah ke berbagai negara di dunia, termasuk Indonesia.

Sehubungan dengan tindakan John Marshal yang melakukan judicial review, Alec stone sebagaimana dikutif oleh Jimly ${ }^{30}$, menyatakan bahwa hakim di Amerika Serikat bertanggung jawab untuk mempertahankan integritas hierarki norma hukum, yang berpuncak pada konstitusi, dan, karena secara yuridis undang-undang berada di bawah norma konstitusi. Oleh karena itu, kaidah-kaidah konstitusi harus berlaku terhadap seluruh konflik hukum yang terjadi dengan undang-undang.Hal ini adalah logika judicial review dan merupakan pandangan terkenal dari Mahkamah Agung Amerika Serikat atas perkara Marbury vs Madison. Akan tetapi, hakim (peradilan umum) negara-negara Eropa diberi tugas untuk menegakkan hierarki peraturan perundangan, yang berpuncak kepada undang-undang, norma legislatif (seperti di Amerika). Artinya, undang-undang berperan penting jika suatu peraturan perundang-undangan bertentangan dengannya (seperti peraturan pemerintah, keputusan, peraturan perundang-udangan daerah, dan lain-lain).

${ }^{30}$ Lihat : Jimly Asshiddiqie, Peradilan Konstitusi di 10 Negara (Jakarta : Sinar Grafka, 2012), hlm. 12-15. 
Jika dicermati tindakan John Marshal dalam melakukan judicial review dan kemudian dikaitkan dengan pengertian konstitusi sebagaimana telah dijelaskan sebelumnya. Maka, putusan John Marshal berlandaskan pada konsitusi sebagai norma hukum dasar suatu negara yang berada pada tingkatan teratas dalam peraturan perundang-undangan, maka peraturan yang berada dibawahnya sudah tentu tidak boleh bertentangan dengannya. Analisa hukum yang mengungkapkan karakter dinamis dari sistem norma dan fungsi norma dasar, juga mengungkapkan suatu kekhasan lebih lanjut dari hukum: hukum mengatur pembentukannya sendiri karena suatu norma hukum menetukan cara untuk membuat norma hukum yang lain, dan juga, sampai derajat tertentu, mentukan isi dari norma yang lain itu. Karena, norma hukum yang satu valid lantaran dibuat dengan cara yang ditentukan oleh suatu norma hukum yang lain, dan norma hukum yang lain menjadi landasan validitas dari norma hukum yang disebut pertama. ${ }^{31}$

Landasan utama yang sangat substansial dilakukannya judicial review adalah untuk menjaga konsistensi peraturan perundang-undangan yang lebih tinggi derajatnya dengan yang lebih rendah. Sebab jika terdapat peraturan perundang-undangan yang tidak sejalan atau konsisten dengan yang lebih tinggi derajatnya, maka undang-undang tersebut tidak konstitusional dan tidak valid. Norma yang tidak valid adalah norma yang secara hukum tidak berlaku dan tidak ada sama sekali, jika suatu undangundang dinyatakan valid maka undang-undang itu bisa valid hanya karena undang-undang tersebut sesuai dengan konstitusi; undang-undang tidak bisa valid jika bertentangan dengan konstitusi. ${ }^{32}$ Lebih jauh menurut

${ }^{31}$ Hans Kelsen. Teori Umum. Op. Cit. hlm. 179.

${ }^{32}$ Ibid. hlm. 223. 
Kelsen, biasanya suatu undang-undang dibatalkan oleh undang-undang yang lain, menurut azas lex superior derogate priori; atau suatu undangundang dibatalkan oleh peraturan hukum kebiasaan yang bertentangan dengannya.

Pentingnya menjaga konsistensi terhadap peraturan perundangundangan dengan menjadikan konsitusi sebagai tolak ukur yang paling tinggi, karena mengingat konstitusi itu sendiri merupakan kerangka masyarakat hukum suatu negara sebagaimana telah disebutkan sebelumnya, yang sudah pasti di dalamnya memuat hal-hal yang sangat urgen, diantaranya mengenai hak azasi manusia, hak dan kewajiban ataupun konsensus antara pemerintah dengan rakyat dan sebagainya. Sehingga segala peraturan peraundang-undangan yang timbul dibawahnya berupa norma hukum baru harus tetap mendapat kontrol atau dikontrol, terlebih lagi karena mengingat perubahan setiap produk hukum yang muncul adalah merupakan hasil konfigurasi politik. Sebagimana dinyatakan oleh Mahfud MD, perubahan tersebut tentunya tidak lepas dari unsur kepentingan politik, karena mengingat bahwa hukum itu adalah produk politik yang pasti tidak steril dari kepentingan-kepentingan politik anggota-anggota lembaga yang membuatnya. ${ }^{33}$ Negara adalah suatu masyarakat yang diorganisasikan secara politik karena negara ini merupakan sebuah komunitas yang dibentuk oleh suatu tatanan yang bersifat memaksa, dan tatanan pemaksa ini adalah hukum. ${ }^{34}$ Semakin masyarakat itu menyadari arti politik itu sendiri, maka masyarakat tersebut

\footnotetext{
${ }^{33}$ Mahfud, Membangun Politik. Op. Cit. hlm. 37.

${ }^{34}$ Hans Kelsen. Teori Umum. Op. Cit. 273.
} 
akan berhati-hati dalam mempergunakan instrument pemerintahan untuk melindungi dan mendahulukan kepentingannya. ${ }^{35}$

Norma yang mengatur penciptaan norma lain berkedudukan lebih tinggi, norma yang diciptakan sesuai dengan norma yang disebut pertama itu berkedudukan lebih rendah. Tatanan hukum bukanlah sebuah sistem norma terkoordinir yang berkedudukan sama, melainkan sebuah hierarki norma hukum dengan berbagai jenjang. ${ }^{36}$ Penerapan peraturan-peraturan konstitusi mengenai pembuatan undang-undang hanya dapat dijamin secara efektif jika suatu organ selain organ legislatif diberi mandat untuk menguji apakah suatu undang-undang (hukum) sesuai atau tidak dengan konstitusi, dan untuk membatalkannya jika-menurut pendapat organ inihukum tersebut "tidak konstitusional".

\section{Penafsiran Terhadap Perppu dan Kedudukannya}

Sebagaimana telah diketahui, bahwa Undang-Undang Dasar 1945 adalah merupakan konstitusi dasar negara yang dijadikan pedoman dalam bernegara dan merupakan bentuk norma hukum tertinggi dari hukum yang lain yang berada di bawahnya. Keberadaan dan kewenangan Mahkamah Konstitusi sebagagai lembaga judicial untuk melakaukan judicial review telah ditetapkan oleh UUD 1945, sebagaimana terdapat dalam Pasal 24 ayat (2) dan $24 \mathrm{C}$ ayat (1).

Terkait dengan permasalahan kewenangan Mahkamah Konstitusi untuk dapat menguji Peraturan Pemerintahn Pengganti Undang-Undang

${ }^{35}$ C.F. Strong. Konstitusi. Op. Cit. hlm. 185.

${ }^{36}$ Hans Kelsen. Teori Hukum Murni. Op. Cit. hlm. 244. 
(Perpu) yang ditetapkan oleh Presiden, ketentuan Perpu diatur dalam Pasal 22 UUD 1945 :

(1) Dalam hal ikhwal kegentingan yang memaksa, Presiden berhak menetapkan peraturan pemerintah sebagai pengganti undangundang.

(2) Peraturan Pemerintah itu harus mendapat persetujuan Dewan Perwakilan Rakyat dalam persidangan yang berikut.

(3) Jika tidak mendapat persetujuan, maka Peraturan Pemerintah itu harus dicabut.

Berdasarkan kewenagan yang dimiliki oleh Mahkamah Konstitusi, secara tekstual MK hanya memiliki kewenangan untuk menguji undangundang terhadap undang-undang dasar berdasar Pasal $24 \mathrm{C}$ ayat (1), dan tidak memiliki kewenangan untuk menguji Perppu terhadap UUD. Namun, permasalahan ini tidak hanya cukup dilihat dari ketentuan tekstual semata, karena mengingat prinsip peraturan perundang-undangan harus searah dan sejalan dari atas sampai ke-bawah dan undang-undang dasar sebagai barometer atau tolak ukur utama dari semua peraturan perundangundangan yang berada di bawahnya. Jika seandainya terdapat perppu yang bertentangan dengan UUD, lalu kemudian tidak ada yang dapat dan berhak mengujinya, hal tersebut akan menyebebabkan terjadinya inkonsistensi dalam peraturan perundang-undangan, terlebih lagi mengingat bahwa hukum adalah produk politik yang tidak pernah steril dari kepentingan orang-orang atau lembaga yang membuatnya. Permasalahan ini ibarat dua sisi mata uang, disatu sisi kewenanangan MK hanya disebutkan menguji undang-undang terhadap undang-undang dasar, dan disatu sisi undang-undang dasar adalah peraturan-perundang yang paling tinggi derajatnya dan peraturan yang berada dibawahnya tidak boleh bertentangan dengannya, termasuk juga perppu, karena perppu terletak di bawah peringkat undang-undang dasar. Mengenenai 
keperingkatan hukum, terdapat sebuah teori hukum yang dikenal dengan Stufenbau des Recht, yangmenurut Hans Kelsen yaitu hukum bersifat hierarkis, artinya hukum itu tidak boleh bertentangan dengan ketentuan yang lebih atas derajatnya. ${ }^{37}$

Mengingat secara teori bahwa dalam peraturan perundangundangan memiliki peringkat, dan kita sudah mengkonstantasi bahwa undang-undang dasar adalah merupakan peringkat tertinggi dari semua peraturan perundang-undangan, maka perlu dilakukan interpretasi terhadap ketentuan Pasal 24 C ayat (1) UUD 1945 dan ketentuan Pasal 22 terkait dengan yang dimaksud kegentingan yang memaksa.

Istilah hal ihwal kegentingan yang memaksa dan darurat di sini tentu tidak boleh dikacaukan atau diindentikkan dengan pengertian “keadaan bahaya” menurut ketentuan Pasal 12 UUD 1945 yaitu "Presiden menyatakan keadaan bahaya. Syarat-syarat dan akibatnya keadaan bahaya ditetapkan dengan Undang-undang”. Keadaan darurat atau dalam hal ihwal kegentingan yang memaksa di sini adalah keadaan yang ditafsirkan secara subjektif dari sudut pandang Presiden/Pemerintah, di satu pihak karena : (i) Pemerintah sangat membutuhkan suatu undang-undang untuk tempat menuangkan sesuatu kebijakan yang sangat penting dan mendesak bagi negara; tetapi di lain pihak (ii) waktu atau kesempatan yang tersedia untuk mendapatkan persetujuan Dewan Perwakilan Rakyat tidak mencukupi sebagaimana mestinya. ${ }^{38}$

Polemik seputar kewenangan MK dalam menguji Peraturan Pemerintah Pengganti Undang-Undang (Perpu), berawal dari putusan MK

${ }^{37}$ Zainuddin Ali, Sosiologi Hukum (Jakarta : Sinar Grafika, 2009), hlm. 2.

${ }^{38}$ Jimly.Pengantar. Op. Cit. hlm. 167. 
No. 138/ PUU-VII/ 2009 tanggal 8 Februari 2010 atas Peraturan

Pemerintah Pengganti Undang-Undang Nomor 4 Tahun 2009 tentang

Perubahan Atas Undang-Undang Nomor 30 Tahun 2002 tentang Komisi

Pemberantasan Tindak Pidana Korupsi yang diajukan oleh Saor Siagian,

SH, dkk. Dalam amar putusannya MK menyatakan : Permohonan para

Pemohon tidak dapat diterima, dan adapun pertimbangan hukum

Mahkamah Konstitusi antara lain:

a. bahwa UUD membedakan antara Perppu dengan Peraturan Pemerintah sebagaimana dimaksud Pasal 5 ayat (2) yang tujuannya adalah untuk menjalankan Undang-Undang sebagaimana mestinya. Karena Peraturan Pemerintah Pengganti Undang-Undang diatur dalam Bab tentang DPR sedangkan DPR adalah pemegang kekuasaan untuk membentuk Undang-Undang maka materi Perpu seharusnya adalah materi yang menurut UUD diatur dengan Undang-Undang dan bukan materi yang melaksanakan Undang-Undang sebagaimana dimaksud oleh Pasal 5 ayat (2) UUD 1945 dan materi Perpu juga bukan materi UUD.

b. bahwa Perpu melahirkan norma hukum dan sebagai norma hukum baru akan dapat menimbulkan: (a) status hukum baru, (b) hubungan hukum baru, dan (c) akibat hukum baru. Norma hukum tersebut lahir sejak Perpu disahkan dan nasib dari norma hukum tersebut tergantung kepada persetujuan DPR untuk menerima atau menolak norma hukum Perpu, namun demikian sebelum adanya pendapat DPR untuk menolak atau menyetujui Perpu, norma hukum tersebut adalah sah dan berlaku seperti Undang-Undang. Oleh karena dapat menimbulkan norma hukum yang kekuatan mengikatnya sama dengan Undang-Undang maka terhadap norma yang terdapat dalam Perpu tersebut Mahkamah dapat menguji apakah bertentangan secara materiil dengan UUD 1945.

c. bahwa Para Pemohon yang berprofesi sebagai advokat tidak dirugikan hak konstitusionalnya oleh berlakunya Perpu 4/2009. Jika pun para Pemohon mengalami kerugian, quod non, maka kerugian dimaksud tidak bersifat spesifik (khusus) dan aktual 
atau setidak-tidaknya potensial yang menurut penalaran yang wajar dapat dipastikan akan terjadi.

d. bahwa Tidak ada hubungan sebab-akibat (causal verband) antara kerugian yang didalilkan oleh para Pemohon dengan berlakunya Perpu 4/2009 yang dimohonkan pengujian dan tidak terdapat jaminan bahwa dengan dikabulkannya permohonan a quo, kerugian konstitusional sebagaimana yang didalilkan tidak lagi terjadi

e. bahwa tidak terdapat jaminan bahwa dengan dikabulkannya permohonan a quo, kerugian konstitusional sebagaimana yang didalilkan tidak lagi terjadi. ${ }^{3}$

Berdasarkan huruf $b$, sebagaimana ringkasan putusan di atas, Mahkamah Konstitusi menyatakan berhak untuk menguji Peraturan Perundang-Undangan (Perpu) terhadap UUD 1945, karena munculnya perpu telah menimbulkan akibat hukum sebagaimana halnya undangundang yaitu (a) status hukum baru, (b) hubungan hukum baru, dan (c) akibat hukum baru. Jadi, materi yang terkandung dalam perpu adalah materi undang-undang, dan menjadikannya sejajar dengannya.Berbeda halnya dengan Peraturan Pemerintah (PP) yang dibuat untuk melaksanakan undang-undang.

Dalam putusan perkara No. 138/ PUU-VII/ 2009, terdapat satu hakim yang mempunyai alasan berbeda (concurring opinion), yaitu Moh. Mahfud MD dan pendapat berbeda (dissenting opinion), yaitu Muhammad Alim, dengan pertimbangan antara lain :

a. Moh. Mahfud, MD

Perppu dapat diuji oleh Mahkamah Konstitusi melalui penekanan pada penafsiran sosiologis dan teleologis. Penekanan pilihan atas

${ }^{39}$ Ringkasan Putusan MK No. 138/PUU-VII/2009

(http://www.djpp.depkumham.go.id/files/litigasi/Putusan\%20PUU\%201382009\%20KPK.pdf). 
penafsiran yang demikian memang agak mengesampingkan penafsiran historis dan gramatik, bahkan keluar dari original intent ketentuan tentang Perpu sebagaimana diatur di dalam Pasal 22 UUD 1945. Hal ini perlu dilakukan justru untuk melindungi kepentingan original intent pasal-pasal dan prinsipprinsip lain yang juga ada di dalam UUD 1945. Pilihan

pandangan ini semata-mata didasarkan pada prinsip dalam menjaga tegaknya konstitusi yakni "tidak boleh satu detik pun ada peraturan perundang-undangan yang berpotensi melanggar konstitusi tanpa bisa diluruskan atau diuji melalui pengujian yudisial."

b. Muhammad Alim

- Pasal 24C ayat (1) UUD 1945, Pasal 10 ayat (1) huruf a Undang-Undang Nomor 24 Tahun 2003 tentang Mahkamah Konstitusi, Pasal 12 ayat (1) huruf a Undang-Undang Nomor 4 Tahun 2004 tentang Kekuasaan Kehakiman hanya menyebut, "Menguji undang-undang terhadap UUD."

- jikalau muatan materi Perpppu bukan muatan yang seharusnya diatur dalam undang-undang, atau materi muatan Perpu yang di luar kewenangan Presiden, atau jelas-jelas bertentangan dengan konstitusi, misalnya Presiden mengeluarkan Perppu yang berisi atau materinya membekukan atau membubarkan DPR, karena bertentangan dengan Pasal 7C UUD 1945, maka Mahkamah Konstitusi berwenang mengadili pengujian Perpu tersebut, walaupun belum mendapat persetujuan atau penolakan dari DPR dalam persidangan yang berikutnya, apalagi kalau materi Perppu itu adalah pembubaran DPR sudah tak ada DPR yang menyetujui atau menolak Perppu tersebut. ${ }^{40}$

Apa yang telah dilakukan oleh Mahfud MD di atas sebagaimana dalam ringkasan putusan, terlihat bertentangan dengan tulisannya yang menyatakan Perppu tidak bisa dimintakan uji materi kepada lembaga yudisial sebab sebagai hukum darurat Perppu hanya diuji melalui political review atau legislative review di DPR pada masa sidang berikutnya setelah

${ }^{40}$ ibid. Ringkasan Putusan.

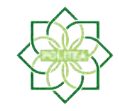


perppu itu diundangkan. Memberikan hak uji materi perppu kepada lembaga yudisial merupakan pelanggaran terhadap Pasal 22 ayat (2) dan ayat (3) UUD $1945 .^{41}$

Senada dengan pendapat di atas sebagaimana halnya dalam ringkasan putusan, menurut Jimly sebelum adanya putusan tersebut, bagaimanapun perppu itu sendiri memang merupakan undang-undang yang dibentuk dalam dalam keadaan yang darurat. Segi substansinya merupakan undang-undang dalam arti materiil, sebab substansi norma yang terkandung di dalamnya adalah materi undang-undang bukan materi peraturan pemerintah. Jadi, substansinya adalah substansi undangundang, tetapi bentuk formalnya adalah Peraturan Pemerintah.Oleh karena itu, perppu dianggap sederajat kedudukannya dengan undangundang sehingga materi muatannya sangat mungkin bertentangan atau bersifat mengubah ketentuan undang-undang yang ada sebelumnya. ${ }^{42}$ Bahkan, jika dicermati, kesamaan kedudukan antara Perppu dengan undang-undang dan dianggap sebagai bentuk undang-undang, maka perppu dapat diuji oleh MK, hal ini dapat dilihat pada Pasal 9 ayat (1) UU No.12 tahun 2011, yaitu "Dalam hal suatu Undang-Undang diduga bertentangan dengan Undang-Undang Dasar Negara Republik Indonesia Tahun 1945, pengujiannya dilakukan oleh Mahkamah Konstitusi”

Menurut logika sederhana, UUD 1945 yang merupakan bentuk peraturan perundang-undangan tertinggi yang sudah konstantasikan menjadi barometer atau tolak ukur bagi perturan perundang-undangan yang berada dibawahnya, maka sepatutnya peraturan yang terdapat dibawahnya tidak boleh bertentangan dengannya, termasuk di dalamnya

${ }^{41}$ Mahfud Md. Membangun Politik. Op. Cit. hlm. 104-105.

${ }^{42}$ Jimly.Pengantar. Op. Cit. hlm. 169-170. 
perppu. Berdasarkan UUD 1945, tidak ada pernyataan akan siapa yang berhak menguji perppu telah menunjukkan bahwa konstitusi dasar kita masih lemah disebabkan masih memberikan kemungkinan seorang pemerintah untuk melakukan pelanggaran terhadapnya untuk merubah undang-undang denga perppu sekalipun dinilainya dalam keadaan bahaya menurut perspektifnya yang kemudian dapat secara legal melanggar UUD. Perubahan tersebut tentunya tidak lepas dari unsur kepentingan politik, karena mengingat bahwa hukum itu adalah produk politik yang pasti tidak steril dari kepentingan-kepentingan politik anggota-anggota lembaga yang membuatnya.

Jika tidak ada kejelasan akan siapa yang berhak untuk menguji perppu, sama saja halnya dengan melegalkan pemerintah bertindak sewenang-wenang untuk melanggar konstitusi dasar melalui perppu, dan tidak ada lagi upaya yang dapat ditempuh bagi orang-orang yang merasa hak konstitusionalnya dilanggar, maka salah satu-satunya cara untuk menghadapinya adalah memohon perlindungan kepada Tuhan. Hal ini senada menurut pendapat John Lock dalam hal tindak criminal yang hanya kuat menjerat rakyat namun tidak kuat menjerat sang penguasa. Menurut John Lock, sebagaimana dikutif oleh Dennis. F. Thompson menyatakan "bila para pejabat bertindak berlawanan dengan kepercayaan yang diberikan, tradisi liberal menawarkan kepada warga pengikutnya bantuan terakhir dengan naik banding dengan "naik banding ke surga"”. 43

Sekilas, apa yang telah dilakukan oleh Mahfud MD dkk serupa dengan apa yang telah dilakukan oleh John Marshall pada tahun 1803, yakni suatu penemuan baru dalam bidang hukum tata negara, terlepas

${ }^{43}$ Dennis F.Thompson. Etika Politik Pejabat Negara (Jakarta : Obor Indonesia, 2002), hlm. 90. 
dari kontroversi sikap yang diambil oleh MK tersebut. Putusan MK yang menyatakan bahwa MK berwenang menguji Perpu adalah perkembangan baru yang positif dalam hukum ketatanegaraan Indonesia yang tidak saja mengikat para pihak, akan tetapi menjadi jurisprudensi dalam hukum ketatanegaran di Indonesia. Dengan putusan tersebut, kemungkinan penyalahgunaan kekuasaan melalui Perppu dan kelemahan sistemik dalam UUD 1945 dalam mengawasi produk Presiden tersebut menjadi terantisipasi yang dengan sendirinya pula akan lebih memberikan perlindungan hukum bagi para pencari keadilan. ${ }^{44}$

Berdasarkan uraian di atas, perlu diadakannya tinjauan terhadap keberadaan perppu di dalam hirarki peraturan perundang-undangan dan penyusunan perppu, hal ini untuk menjaga agar tidak terjadinya inkonsistensi dalam hiarki peraturan perundang-undangan sehingga tidak memunculkan undang-undang yang tidak konstitusional, dan jika dianggap tidak konstitusional maka peraturan tersebut harus dapat diuji selama berada di dalam tatanan hirarki peraturan perundang-undangan. Hal tersebut hanya dapat dilakukan oleh sebuah organ atau lembaga negara yang disebut sebagai pengadilan konstitusi untuk melakukan pengawasan kekonstitusionalan suatu undang-undang yang disebut judicial review. ${ }^{45}$

Jika memang Peraturan Pemerintah Pengganti Undang-Undang (Perppu) diinginkan/dikehendaki untuk tidak dapat diuji, maka sebaiknya perppu diatur tersendiri secara terpisah dengan tegas dalam suatu ketentuan peraturan perundang-undangan dengan tidak menempatkannya dalam tatanan hirarki peraturan perundang-undangan, sehingga tidak

${ }^{44}$ Manunggal K Wardaya. Perubahan Konstitusi Melalui Putusan MK (Jurnal Konstitusi, Vol 7, Nomor 2, April 2010)

${ }^{45}$ Lihat : Hans Kelsen. Teori Umum Tentang Hukum .Op. Cit. hlm. 225. 
memberikan ruang multi tafsir terhadap keberadaannya bagi kalangan terkait. Terlebih lagi kelemahan di dalam tatanan hirarki peraturan perundang-undangan, sebagaimana kini terdapat di dalam Pasal 7 UU No.

12 Tahun 2011 sebagaimana telah disebutkan, perppu berada pada peringkat ke-tiga sejajar dengan undang-undang dan diselingi oleh tanda (/) yang lumrah diartikan "atau" yang menunjukkan bahwa antara undangundang dan perppu pada dasarnya adalah sama-sama merupakan suatu peraturan perundang-undangan. Coba bandingkan dengan ketentuan Huruf (g) yang terdapat pada Pasal 7 UU No. 12 Tahun 2011 yaitu "Peraturan Daerah Kabupaten/Kota", tanda yang terdapat dalam ketentuan tersebut yaitu garis miring (/), menunjukkan bahwa antara Perda Kabupaten dan Kota adalah sama derajatnya atau setingkat dan dapat dilakukan pengujian terhadapnya. Bila dianalogikan dengan ketentuan Huruf (c) yaitu "Undang-Undang/Peraturan Pemerintah Pengganti Undang-Undang", maka seharusnya ketentuan pada pada huruf (c) ini harus diartikan sama dengan ketentuan huruf (g), karena penggunaan lambang yang dipakai adalah sama. Penggunaan tanda atau lambang dalam ketentuan peraturan perundang-undangan perlu mendapat perhatian dan dikaji ulang, dan harus digunakan secara proporsi guna mencapai keprofesionalan, sehingga tidak menimbulkan ambiguitas dalam penafsiran yang saling kontradiktif.

\section{G.Kesimpulan}

Berdasarkan uraian pembahasan dari di atas sebagaimana telah dijelaskan, kesimpulan yang dapat diambil dari fokus bahasan mengenai Kewanangan Mahkamah Konstitusi dalam menguji Peraturan Pemerintah Pengganti Undang-undang (Perppu), yaitu: 
Jika hanya berdasarkan kepada teks Pasal 24 C ayat (1) UUD 1945 yang mengatur kewenangan Mahkamah Konstitusi (MK), maka MK tidak diperkenankan untuk menguji Perppu terhadap UUD 1945. Namun, Mahkamah Konstitusi (MK) dapat menguji Perppu terhdap UUD 1945, jika Perppu dinyatakan sama kedudukannya dengan undang-undang yang menciptakan norma hukum baru, yang menurut teori peraturan perundang-undangan harus tetap berada pada tatanan hirarkis untuk menjalin konsistensi antara peraturan perundang-undangan yang lebih tinggi derajatnya dengan yang lebih rendah, karena mengingat konstitusi adalah merupakan hukum dasar suatu negara yang memuat permasalahan yang sangat substansial bagi kelangsungan negara dan menjadi sumber atau rujukan bagi peraturan yang berada dibawahnya, maka peraturan yang berada dibawahnya harus sesuai dengannya, termasuk Peppu yang harus sesuai dengan UUD 1945, sebab pembentukan atau perubahan suatu peraturan tidak pernah steril dari kepentingan politik golongan tertentu. Untuk itu semua peraturan yang berada di bawah konstitusi harus dapat diuji untuk menjamin konsistensi perundang-undangan oleh suatu lembaga, sebab peraturan yang tidak konsisten adalah tidak konstitusional dan tidak dapat diberlakukan. Sebagaimana halnya sejarah judicial review muncul, pada saat yang bersamaan tidak terdapat ketentuan untuk melakukan hal tersebut, maka MK juga dapat melakukan pengujian Perppu terhadap UUD 1945 dalam rangka mengawal dan menegakkan konstitusi serta sebagai temuan baru dalam hukum ketatanegaraan Indonesia. Terlebih lagi penggunaan tanda atau lambang dengan garis miring (/) tidak dapat digunakan secara proporsional dan professional serta dapat memunculkan penafsiran variatif atau multi tafsir 
serta melahir kan kontradiksi antara dua pendapat yang berbeda, sebagaimana telah dijelaskan sebelumnya.

\section{Daftar Pustaka}

Asshiddiqie, Jimly. 2005. Hukum Tata Negara Dalam Pilar-Pilar Demokrasi. Jakarta : Konpress

Asshiddiqie, Jimly. 2010. Konstitusi dan Konstitualisme Indonesia. Jakarta : Sinar Grafika.

Asshiddiqie, Jimly. 2010. Pengantar IImu Hukum Tata Negara. Jakarta : Raja Grafindo.

Asshiddiqie, Jimly.2012. Peradilan Konstitusi di 10 Negara.Jakarta : Sinar Grafika

Dimyati, Khuzaifah. 2010. Teorisasi Hukum.Yogyakarta : Genta.

Fuady, Munir. 2009. Teori Negara Hukum Modern.Bandung : Refika Aditama.

Fuady, Munir. 2010. Perbandingan Ilmu Hukum. Bandung : Refika Aditama.

F. Thompson, Denis. 2002. Political Ethics and Public Office dalam Etika Politik Pejabat Negara (penerjemah: Benyamin Molan). Jakarta : Yayasan Obor Indonesia.

Ismatullah, Dedi dkk. 2009. Hukum Tata Negara. Bandung : Pustaka Setia. Juniarto.Selayang Pandang Sumber-sumber Hukum Tata Negara di Indonesia. Jakarta : Rineka Cipta 
Kelsen, Hans. 2010. Teori Umum Tentang Hukum dan Negara Hukum dalam The General Theory of State (Pen: Raisul Muttaqien).Bandung : Nusa Media.

Kelsen, Hans. 2010. Pure Theory of Law dalam Teori Hukum Murni (Pen: Raisul Muttaqien).Bandung : Nusa Media

Kusnardi, Moh dkk. 1994. IImu Negara. Jakarta : Gaya Media.

Lubis, Solly. 2001. Ilmu Pengetahuan Perundang-undangan. Bandung : Mandar Maju.

Magnis, Franz Suseno. 1999. Etika Politik Prinsip Moral Dasar Kenegaraan Modern.Jakarta: Gramedia.

MD, Mahfud. 2011. Membangun Politik Hukum, Menegakkan Konstitusi. Jakarta : Raja Grafindo.

MD, Mahfud. 1998. Politik Hukum. Yogyakarta : LP3ES.

Strong.C.F. 2010.Modern Politcal Constitution dalam Konstitusi-Konstitusi Politik Moedern (Pen: Derta Sri Widowatie). Bandung : Nusa Media.

Susanto, Agung. 2006. Hukum Acara Perkara Konstitusi. Bandung : Mandar Maju.

Raharjo, Satjipto. 2006. Ilmu Hukum. Bandung : Citra Adikarya, cet ke-vi.

Riyanto, Astim. 2006. Teori Konstitusi. Bandung : Yapemdo.

Soehino. 1980. Ilmu Negara. Yogyakarta : Liberty.

Jurnal Konstitusi, Volume 7, nomor 2, April 2010. 
Mahkamah Konstitusi Republik Indonesia, Menegakkan Negara Hukum Yang Demokratis: Catatan Tiga Tahun Perjalanan Mahkamah Konstitusi 2003-2006. Jakarta : Sekretariat Jendral dan Kepaniteraan MK RI, 2006

Suripto.Makalah 2007. Wewenang Mahkamah Konstitusi Menguji Undangundang. Jakarta : Setneg

Undang Undang Dasar 1945 


\section{DAFTAR PUSTAKA}

Hamid, Ihsan, 'Black Campaign', Detik FD, 2020

< http://ihsan.org/blackcampaign> [accessed 2 December 2020]

, Sistem Politik Indonesia (Mataram: FD Publishing, 2020)

Hamid, Ihsan, and Rizky HK, 'Analisis Partisipasi Politik Warga Pada

Pilkada NTB Tahun 2018', Politeal: Jurnal Politik Islam, 3.1 (2020), 1100

Hamid, Ihsan, and Agus Dedi Putrawan, 'Politik Ormas', in Dinamika Civil Society Di Lombok (Mataram: FD Publishing, 2020), pp. 54-70

Post, FD, 'Pemilu Serentak Dijadwal Ulang' (Mataram, 2 December 2020), p. 7

Wahyudi, Very, 'Potret Buram Politik Indonesia', in AICIO (Mataram: FD

Publishing, 2020), III, 50-60 
